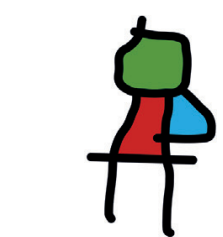

SEICAIP

\section{Allergologia et immunopathologia}

Sociedad Española de Inmunología Clínica, Alergología y Asma Pediátrica

www.all-imm.com

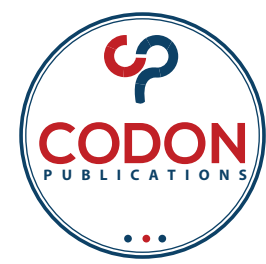

ORIGINAL ARTICLE

OPEN ACCESS (C)(1)(2)

\title{
Analysis of specific antibody and cellular immune response to first-dose measles vaccine Edmonston-Zagreb in 9-month-old infants
}

\author{
Teni Nurlatifah HR ${ }^{a, b}$, Wisnu Barlıantoc*, I Wayan Arsana Wiyasad, H.M.S. Chandra \\ Kusumac, Tita Luthfia Saric, Novilia Sjafri Bachtıare
}

${ }^{a}$ Applied Midwifery, Master's Study Program of STIKes Dharma Husada Bandung, West Java, Indonesia ${ }^{b}$ Doctoral Program of Medical Science, Faculty of Medicine Universitas Brawijaya Malang 'Pediatric Department, Faculty of Medicine, Brawijaya University, Veteran Street, Malang 65145, East Java, Indonesia ${ }^{d}$ Obstetric and Gynecology Department, Faculty of Medicine, Brawijaya University, Veteran Street, Malang 65145, East Java, Indonesia ${ }^{e}$ Bio Farma, Pasteur Street No. 28, Bandung 40161, West Java, Indonesia.

Received 21 October 2020; Accepted 19 February 2021

Available online 1 May 2021

\section{KEYWORDS \\ antibodies; \\ IFN-y; \\ IL-17A; \\ measles-vaccines; \\ T cells}

\begin{abstract}
Background: Measles vaccinations have been suggested to provide immune protection and decreased measles incidence. However, there was a limited study evaluating how the measles vaccine elicits specific immune responses.

Objective: This study aimed to evaluate both humoral and cellular immunity to first-dose measles vaccine Edmonston-Zagreb (EZ) in 9-month-old Indonesian infants.

Methods: A cohort study was conducted on 9-month-old infants who got the first-dose of measles vaccine EZ. Measles-specific immunoglobulin G (IgG) antibody serum levels were measured using plaque-reduction microneutralization assay. Peripheral blood mononuclear cells were stimulated with a measles-specific peptide to identify a cellular immune response. Quantification of $\mathrm{CD}^{+}$and $\mathrm{CD}^{+}$T-cells producing interferon-gamma (IFN- $\mathrm{y}$ ) and interleukin 17-A (IL-17A) were conducted by flow cytometry. Humoral and cellular immune response parameters were analyzed over time.

Results: The prevalence of seropositivity rates was $85.8 \%$ at 1 -month after vaccination and $16.67 \%$ at 6 -months postvaccination. Measles-specific IgG antibodies increased significantly at 1-month after measles vaccination. However, they decreased significantly 6-months after vaccination. IFN-y and IL-17A secreting T-cells increased significantly at 1-month after measles vaccination. Interestingly, a significant decrease of IFN-y and IL-17A secreting CD4+ $\mathrm{T}$ cells was noticed 6-months postvaccination compared to IFN- $\gamma$ and IL-17A secreting CD8 ${ }^{+} T$ cells.

Conclusion: Our study suggests that the first-dose measles vaccine on 9-months-old infants seems to induce both humoral and cellular immune responses that decline 6-months after vaccination. (c) 2021 Codon Publications. Published by Codon Publications.
\end{abstract}

*Corresponding author: Wisnu Barlıanto, Pediatric Department, Faculty of Medicine, Brawijaya University, Veteran Street, Malang 65145, East Java, Indonesia, Email address: wisnu_barlian@ub.ac.id

https://doi.org/10.15586/aei.v49i3.6

Copyright: Teni Nurlatifah HR, et al.

License: This open access article is licensed under Creative Commons Attribution 4.0 International (CC BY 4.0). http://creativecommons.org/ 


\section{Introduction}

Measles virus (MV) is the causative agent of measles, an acute systemic infection predominantly found in young children. It is a highly contagious disease associated with high rates of morbidity and mortality among children. The highest case-fatality rates occur in children $<12$ months old. ${ }^{1}$ The average number of infections reported to the Centers for Disease Control and Prevention ranged from 3-4 million in the pre-vaccination era, and there were around 1.2 million deaths attributed to measles. ${ }^{2}$ The global reductions in incidence from 2006 were due to the successful vaccination programs. Measles vaccinations are reportedly effective in providing immune protection and decreasing measles incidence. However, several countries still report measles outbreaks despite the vaccination program. Since 2006, the 2017-2019 period demonstrated the highest upwards fluctuation of measles incidence globally $(401.024$ cases in 2019). ${ }^{3}$ Indonesia's coverage with the first dose of the measles vaccine increased from 75-90\%.4,5 However, there were over 12,000 reported measles cases annually in the past five years in Indonesia. ${ }^{6}$ An outbreak of 800 in a single district earlier in 2017 also resulted in 72 child deaths. ${ }^{7}$ Moreover, it has been reported that several measles infections still occurred in Indonesian children who had the measles vaccination history. ${ }^{5}$ To date, no study evaluated the effectiveness of measles vaccination program in Indonesia. Hence, this study was the first pilot study that analyzed immune responses the following first dose of measles vaccination in Indonesia.

The measles vaccine is a live, attenuated virus that will induce both humoral and cellular immune responses. ${ }^{8}$ The initial immune response of measles infection was characterized by an increase of interferon- $\gamma$ (IFN- $\gamma$ ) producing $\mathrm{T}$ cells. A shift in cytokine production was noticed later, where the IFN- $x$ in the early phase was replaced by interleukin-4 (IL-4), IL-10, IL-13 and IL-17A.9,10 This promoted $B$ cell maturation and contributed to the production of antibodies. ${ }^{11}$ A study by Martin et al..$^{12}$ reported that protective measles antibody levels were developed rapidly after vaccination and persisted even after the second dose of vaccine. But another study showed that measles vaccination of six months old infants revealed poor humoral immunogenicity, ${ }^{13}$ This which was attributed to the interference of passively acquired antibodies from maternal and limitations of the developing immune system in infants. ${ }^{14}$ It also has been speculated that measles vaccine failure can also be because of the induction of a polarized cytokine profile, which contributes to an immune response that may not be sufficiently protective. ${ }^{11}$ However, there were conflicting results about cytokine production patterns and protective immunity in the measles vaccine..$^{15}$

Studies have been reported that measles-specific $\mathrm{T}$ cell-mediated immunity was elicited by primary measles vaccination. ${ }^{13,14,16}$ Early dose of measles vaccination of 6-months-old infants increases the $\mathrm{T}$ cell responses which may prime the humoral response. Previous studies also reported that the primary measles immunization was sustained for 5-10 years of age regardless of the time it was administered. ${ }^{14}$ These results suggested a pivotal role of cellular immune responses to the measles vaccine. Only a limited study evaluating the cellular immune response induced by $\mathrm{CD}^{+}$and $\mathrm{CD}^{+} \mathrm{T}$ cells in the measles vaccination. This is partly because of the experimental difficulties of stimulation induction and limited technical methods to provide precise quantification of measles virus-specific $T$ cells. Hence, this study aimed to evaluate the humoral and cellular immunity to first dose measles vaccine Edmonston-Zagreb (EZ) in 9-month-old Indonesian infants.

\section{Material and methods}

\section{Research participants}

An observational cohort study was conducted on 9-monthhealthy infants who were not immunized with the measles vaccination or had not got measles infection before. This study was performed in the Primary Health Center, Plumbon, Cirebon, West Java, Indonesia. The EZ strain of the measles vaccine and the MR vaccine (Batch Number 0128W0780 and 0128W0800) was provided by the Serum Institute of India (Pune, India). This study used the obtained measles vaccination as the first dose of the routine vaccination program for 9-month-old infants in Indonesia. The study included 35 infants (19 males and 16 females) between 9-12 months. Participants who had concurrent medical problems (such as malnutrition, infection, malignancy, a congenital or genetic disease), had prior measles infections and had received measles vaccinations in the past were excluded from this study. Informed written consent was obtained from the parent or parents, and $3 \mathrm{ml}$ of peripheral blood samples were obtained by venepuncture before vaccination and at one and six months after vaccination. The research design is shown in Figure 1.

\section{Peripheral blood mononuclear cells isolation, culture and stimulation}

The peripheral blood sample was separated by the FicollPaque method to separate red blood cells. These red blood cells were separated for PBMC fraction and plasma. The cellular fractions were subjected to flowcytometry analysis (XL, Beckman Coulter, Miami, FL, USA) to obtain the absolute cell population numbers $\left(10^{5}-10^{6}\right.$ cells per well). Later

$\begin{array}{lc}\begin{array}{l}\text { Age at time of early dose measles vaccine } \\ 9 \text { months old }(n=35) \\ \text { Baseline blood sample }\end{array} & \begin{array}{c}\text { Measles vaccine } \\ \text { EZ }\end{array} \\ \text { Age at follow-up time point } 1 & \begin{array}{l}10 \text { months old }(n=35) \\ \text { 2nd blood sample }\end{array} \\ \text { Age at follow-up time point } 2 & 16 \text { months old }(n=35) \\ \text { 3rd blood sample }\end{array}$

Figure 1 Research design representing the timing of the first measles vaccine and immune evaluations. Blood samples were collected at 1- and 6-months after the first-dose measles vaccine. 
the cell suspension was incubated in a serum-free medium (Roswell Park Memorial Institute medium 1640, sodium bicarbonate, HEPES, and $1.25 \%$ penicillin-streptomycin), and complete medium at $5 \%$ carbon-di-oxide and $37^{\circ} \mathrm{C}$ for 24 hours. The cell suspension was then stimulated for 12 hours using $\mathrm{H} 61$ and $\mathrm{H} 1$ peptides $(1 \mu \mathrm{g} / \mathrm{ml})$ and peptide diluent dimethyl sulfoxide (DMSO). The $\mathrm{H} 61$ and $\mathrm{H} 1$ peptides were overlapping peptides, representing measles virus proteins, which were already synthesized and obtained from GENSCRIPT. ${ }^{17}$

\section{Flow cytometry analysis of $T$ cells expressing IFN- $y$ and IL-17A}

The cell suspensions were surface labeled with CD4 (FITC Anti-human CD4 Antibody (Biolegend, Cat.no. 317408) and CD8 antibodies (PE/Cy5 Anti-human CD8a Antibody) (Biolegend, Cat.no. 300910). Later, it was permeabilized for $10 \mathrm{~min}$ in $4 \%$ paraformaldehyde and $1 \%$ saponin buffer before intracellular cytokine staining. Intracellular cytokine staining identifies $T$ cells expressing IFN- $\gamma$ (PE Antihuman IFN-Y Antibody; Biolegend, Cat.no. 502509) and IL-17A (PE Anti-human IL-17a Antibody; Biolegend, Cat.no. 512306). Flow cytometry acquisition and analysis were performed on a FACSCalibur (BD Biosciences, Franklin Lakes, NJ, USA).

\section{Measles-specific immunoglobulin-G antibody measurement}

A neutralization test evaluated the Measles-specific immunoglobulin-G (IgG) antibody level. The sample was heat-inactivated in a $56^{\circ} \mathrm{C}$ water bath for $30 \mathrm{~min}$. Two-fold serial dilutions (1:2 to 1:256) of specimens along with positive and negative control sera were prepared in Dulbecco's Modified Eagle Medium (DMEM) media (Sigma-Aldrich, St. Louis, MO, USA). Fifty microliters of the median tissue culture infectious dose were added to $50 \mu$ of each serum dilution and controls in microtiter plates and were placed on a shaker before being transferred to an incubator at $36^{\circ} \mathrm{C}$ for an hour. Post incubation, $50 \mu \mathrm{l}$ of the serum-virus mixture was transferred to appropriate wells of another microplate containing monolayers of VERO cells and incubated at $36^{\circ} \mathrm{C}$ for $1 \mathrm{~h}$ for the adsorption of the virus on the monolayers. Later, $100 \mu \mathrm{l}$ of DMEM containing antibiotics and $2 \%$ fetal bovine serum were added to each well. A cellular (normal cells and medium without virus and serum) and viral controls $(50 \mu \mathrm{l}$ of the prepared virus in $50 \mu \mathrm{l}$ DMEM without serum) were also maintained for each plate. The microtiter plates were then placed on a $36^{\circ} \mathrm{C}$ incubator and checked for seven days for the presence of cytopathic effect (CPE). The highest test serum dilution that could prevent CPE of the measles virus was recorded as a measles antibody titer. ${ }^{18} \mathrm{~A}$ protective neutralizing antibody titer was $>1: 8$, and the antibody level was converted in $\mathrm{mlU} / \mathrm{ml}$. According to the 2nd International Standard for measles antibody assigned by the World Health Organization (WHO) Expert Committee on Biological Standardization, an antibody level $\geq 120 \mathrm{mlU} / \mathrm{mL}$ was considered as seropositive and safe. ${ }^{19}$ The minimum antibody concentration detectable in our study was $106.95 \mathrm{mlU} / \mathrm{ml}$. Measles IgG-specific antibody measurement was conducted at the Biofarma Laboratory (Bandung, Indonesia).

\section{Statistical analysis}

Descriptive statistics were used to analyze the demographic characteristics of subjects. The dependent variables were measles-specific antibody level, CD4 and CD8 T cells expressing IFN- $\gamma$ and IL-17A. Comparative analysis of variables between time of evaluation was performed by analysis of variance or Kruskal-Wallis test. The Pearson or Spearman test was used to measure the antibody level and cellular immune response association to the measles vaccine. Data analyses were performed using the software program IBM SPSS Statistics, Version 25.0 (IBM SPSS Statistics, Armonk, NY, USA). $\mathrm{P} \leq 0.05$ were considered significant.

\section{Results}

\section{Research participant characteristics}

Demographic data including age, gender, weight, length and body mass index were collected at the first visit and are shown in Table 1.

The study included 35 infants (19 males and 16 females) with a median age of 10 (9-12) months who were in healthy condition and were due for their measles vaccination and had not contradicted measles natural infection. The mean weight and height at enrolment were $9.81 \pm 4.27 \mathrm{~kg}$ and $71.67 \pm 2.80 \mathrm{~cm}$, respectively. From the anthropometric analysis, four (11.4\%) infants were classified as underweight. Seven (20\%) were categorized with short stature.

\section{Profile of measles-specific IgG antibody}

All the participants had a measles-specific IgG antibody level $<120 \mathrm{mIU} / \mathrm{mL}$ at baseline which meant that they had

Table 1 Demographic data of research participants.

\begin{tabular}{lc}
\hline Characteristics & \\
\hline Sex, $\mathrm{n}(\%)$ & $19(54.3)$ \\
$\quad$ Male & $16(45.7)$ \\
$\quad$ Female & $10(9-12)$ \\
Age, months (Median (min-max)) & \\
Anthropometric data & $9.81 \pm 4.27$ \\
$\quad$ Weight, kg (mean \pm SD) & $71.67 \pm 3.80$ \\
Height, cm (mean \pm SD) & $18.34 \pm 3.26$ \\
BMl, kg/m² (mean \pm SD) & \\
Z-score weight for age (n) (\%) & $31(88.6)$ \\
$\quad$ Normal & $4(11.4)$ \\
Underweight & \\
Z-score height for age (n) (\%) & $28(80)$ \\
$\quad$ Normal & $7(20)$ \\
Short stature
\end{tabular}


no protective antibody against measles or were susceptible to infection and disease. There were changes in the mean of measles-specific IgG antibody level at 1- and 6-months postvaccination. The prevalence of seropositivity rates at 1-month was $85.8 \%$ and only $16.67 \%$ at 6 -months postvaccination. The Kruskal-Wallis and Mann-Whitney test were performed on the measles-specific IgG antibody level mean to assess its dynamics. There was a significant increase in the measles-specific IgG antibody level between baseline and 1-month after vaccination $(P<0.001)$. At 6-months after vaccination, we found that the measles-specific IgG antibody level decreased significantly compared to 1-month after vaccination $(P<0.001)$. However, measles-specific IgG antibody level at 6-months was higher than baseline $(P=0.015$; Figure 2; Table 2).

\section{Characterization of $C D 4^{+}$and $C D 8^{+} T$ cells producing IFN-g and IL-17A}

This study evaluated the number of $\mathrm{CD}^{+}$and $\mathrm{CD} 8^{+} \mathrm{T}$ cells expressing IFN-g and IL-17A from PBMC after stimulation with measles-specific peptide. Both $\mathrm{CD}^{+}$and $\mathrm{CD}^{+}{ }^{+} \mathrm{T}$ cells could be induced to produce IFN-g and IL-4, respectively. Table 2 shows the profile and range of the measles vaccine-induced cellular immune responses over time. We found a significant increase of $\mathrm{CD}^{+} \mathrm{T}$ cells expressing IFN-g at 1-month after vaccination $(P<0.001)$. However, it was decreased significantly at 6 -months compared to 1 -month after vaccination ( $P=0.003$ ). No significant difference was observed in the number of $\mathrm{CD}^{+} \mathrm{T}$ cells expressing IFN-g at 6-months and baseline, but it was still higher at 6-months after vaccination $(P=0.246)$. The number of $C D 8^{+} T$ cells expressing IFN-g also increased significantly at 1-month $(\mathrm{P}<0.001)$ and decreased at the 6-month but without any altered statistical difference $(P=0.329)$. Even though there was a decline in $\mathrm{CD}^{+} \mathrm{T}$ cells expressing IFN-g, the number of $\mathrm{CD}^{+} \mathrm{T}$ cells was still higher than that in the baseline $(\mathrm{P}<$ 0.001; Figure 3).

Both $\mathrm{CD}^{+}$and $\mathrm{CD}^{+} \mathrm{T}$ cells producing IL-17A increased significantly at 1-month after vaccination compared to baseline $(P=0.002, P<0.001$, respectively). The number of $\mathrm{CD}^{+} \mathrm{T}$ cells producing IL-17A also decreased at 6-month versus 1 -month after vaccination $(P=0.018)$, and no significant difference with baseline $(p=0.608)$ was observed. We also reported a decreasing number of $C D 8^{+} T$ cells producing IL-17A at 6-months after vaccination, even though it was not significantly different $(P=0.464)$. The number of $C D 8^{+}$ $T$ cells producing IL-17A at 6-months was higher than that in the baseline $(P=0.015$; Figure 4$)$.

\section{Correlation between measles-specific lgG antibody and cellular immune response.}

This study demonstrated an increased measles-specific IgG antibody levels and T cells mediated immune response after the first dose of measles vaccination. From the

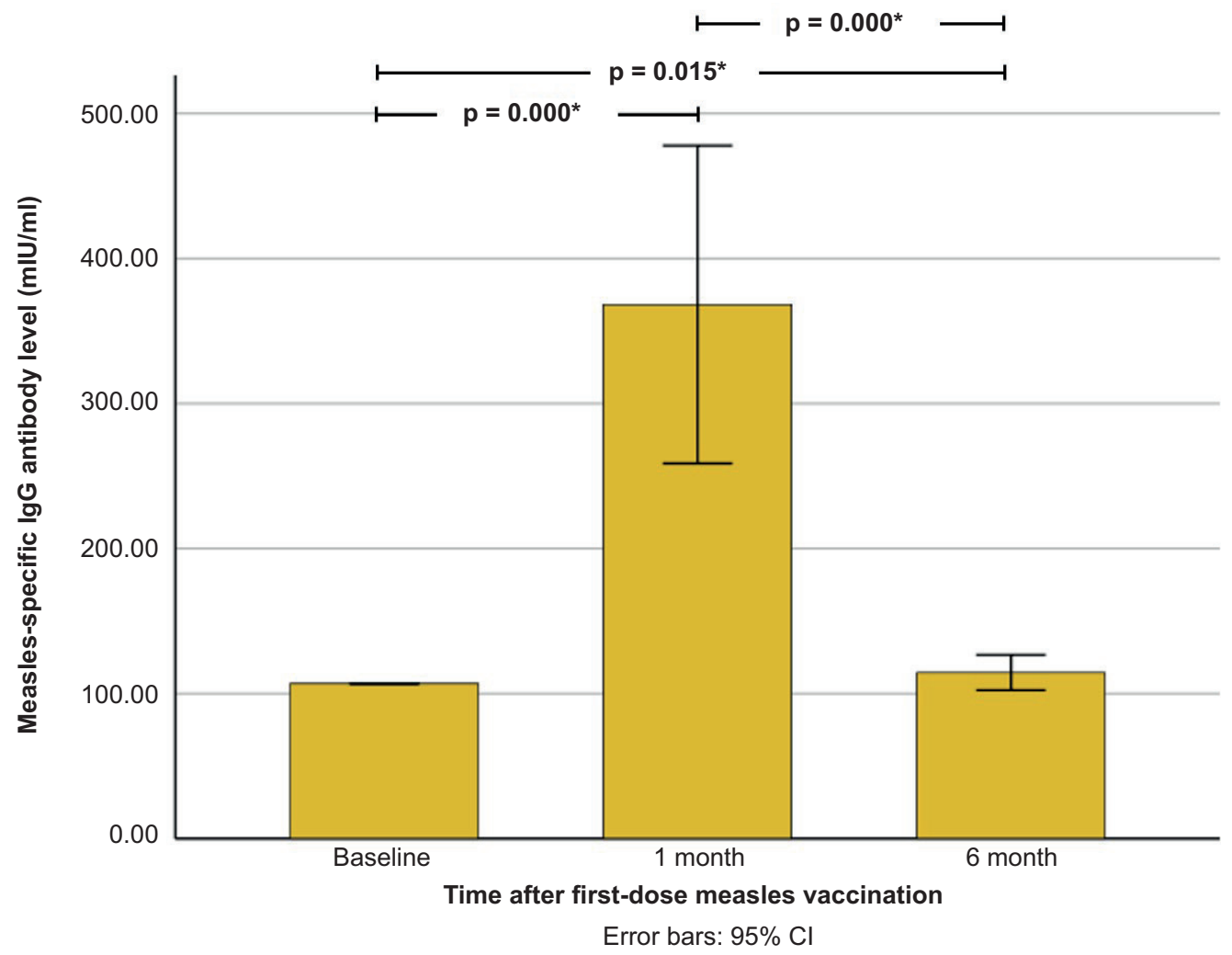

Figure 2 Comparison of measles-specific IgG antibody level over time of evaluation. ${ }^{*} p<0.05$ was statistically significant (Mann-Whitney test). 
Table 2 Profile of measles-specific humoral and cellular immune responses. ${ }^{a}$

\begin{tabular}{|c|c|c|c|c|}
\hline Immune response parameters & Baseline $(n=35)$ & $\begin{array}{l}\text { 1-month after first dose } \\
\text { measles vaccine }(n=35)\end{array}$ & $\begin{array}{l}\text { 6-months after first dose } \\
\text { measles vaccine }(n=12)\end{array}$ & $\mathrm{p}$ Value \\
\hline IgG antibody (mlU/ml) & 106.95 & $368.25 \pm 319.06$ & $114.48 \pm 19.12$ & $0.000^{*}$ \\
\hline Seronegativity rate, n (\%) & $35(100)$ & $5(14.20)$ & $10(83.33)$ & \\
\hline Seropositivity rate, $\mathrm{n}(\%)$ & 0 & $30(85.80)$ & $2(16.67)$ & \\
\hline $\mathrm{CD} 4^{+} \mathrm{IFN}-\mathrm{\gamma}^{+}(\%)$ & $3.45 \pm 2.04$ & $7.37 \pm 3.72$ & $4.22 \pm 1.25$ & $0.000^{*}$ \\
\hline CD8 ${ }^{+}$IFN- $\gamma^{+}(\%)$ & $1.78 \pm 2.03$ & $5.19 \pm 3.43$ & $3.84 \pm 1.67$ & $0.000^{*}$ \\
\hline $\mathrm{CD}^{+} \mathrm{IL}^{-17 \mathrm{~A}^{+}}(\%)$ & $4.73 \pm 1.47$ & $6.76 \pm 2.71$ & $4.64 \pm 2.09$ & $0.003^{*}$ \\
\hline CD8+IL-17A+ (\%) & $2.58 \pm 1.15$ & $4.30 \pm 1.96$ & $3.74 \pm 1.48$ & $0.000^{*}$ \\
\hline
\end{tabular}

Spearman correlation analysis, a significant positive correlation between the number of $\mathrm{CD}^{+}$and $\mathrm{CD} 8^{+} \mathrm{T}$ cells producing IFN-y and IL-17A and measles-specific IgG antibody level $(P<0.05)$ was established. However, from the correlation coefficients, we observed no significant correlation between variables (Table 3).

\section{Discussion}

Several studies have been conducted to assess the effectiveness and antibody response to measles vaccines. Only limited information observing both humoral and cellular immune response against the measles vaccine is available. ${ }^{20}$ This study was a pilot study with cohort design conducted on 9-months-old Indonesian infants who received their first-dose measles vaccine EZ. Here relatively high seropositivity rates among vaccinated 9-month-old infants (85.8\%) after 1-month of first-dose measles vaccine. Several studies reported that approximately $85 \%$ of children develop protective antibody levels when given one dose of measles vaccine at nine months of age, and $90-95 \%$ respond when vaccinated at 12 months of age. ${ }^{8}$ A cohort study conducted in California reported similar results, the seroconversion rate in 9-month-old infants, 12 weeks after measles vaccination, was $97 \% .^{13}$

It was important to evaluate when the antibodies start to provide decline to provide protection. The study by LeBaron et al. ${ }^{21}$ showed that involved as many as 364 participants in the United States showed that measles antibodies increased rapidly one month after vaccination, then begin to decrease gradually, but showed persistent protection levels for up to 10 years after immunization with two doses of the measles vaccine. Another study conducted in Pakistan reported that the early EZ measles vaccine in 9-month-old infants raised protective antibody levels in most children. The antibody concentrations increased dramatically within two weeks after immunization and faded slowly with time. ${ }^{22}$ Our study also reported similar outcomes. There was a significant increase of measles-specific IgG antibody level at 1-month and a decline at 6 -months post initial dose of measles vaccine. An indication of re-vaccination was required to increase the antibody titers, already reported in many previous studies. The cohort study by Gans et al. ${ }^{9}$ showed that neutralizing antibody concentrations were lower following the first measles vaccine. However, responses could be boosted by subsequent doses. Several other studies showed that initiating two doses of the measles vaccine were significantly better at increasing antibody levels than a single dose..$^{23-25}$ A systematic review also suggested that administering a first-dose measles vaccine followed by additional measles vaccine doses result in high seropositivity and vaccine effectiveness. ${ }^{20}$

In addition to measles-specific antibody titers, a study by Griffin $^{10}$ also assessed the role of cellular immunity in the immune response to measles vaccination. In measles virus infection, immune activation and lymphocyte proliferation, $\mathrm{CD}^{+}$and $\mathrm{CD}^{+} \mathrm{T}$ cells occur acutely and persist for several months after resolution. During this period, there was a change in the cytokine production pattern from Th1 cell cytokines (IFN- $\gamma$ ) to Th2 cell cytokines (IL-4, IL-10, IL-13) and the appearance of IL-17 production by Th17 cells. This change induces the maturation of $B$ lymphocyte cells into a plasma that secretes specific IgG antibodies. ${ }^{26}$ The in vivo study of Nelson et al. ${ }^{17}$ evaluated the cellular immune responses specific to $\mathrm{T}$ lymphocyte cells on monkeys infected with wild-type strains of the measles virus. They reported an increase in $\mathrm{CD}^{+} \mathrm{T}$ cells and $\mathrm{CD} 8^{+} \mathrm{T}$ cells producing IFN- $\gamma$ and IL-17 to hemagglutinin protein $(\mathrm{H})$ and nucleocapsid $(\mathrm{N})$ on days 2-3, 8, and 18-24 weeks after infection. $T$ lymphocytes producing IFN- $\gamma$ increase in the initial phase of infection while IL-17A increases in the final phase.

However, in this study we found that $\mathrm{CD}^{+}$and $\mathrm{CD} 8^{+}$ $\mathrm{T}$ cells were equally prominent and produce both IFN- $\gamma$ and IL-17A at 1-month postvaccination that agreed with the study evaluating cytokine secretion patterns following the measles vaccine in infants. It showed that cytokines (IL-2, IL-6 and IFN- $\gamma$ ) increased on day 30 postvaccination to levels greater than baseline levels. ${ }^{15}$ These results showed that both Th1 and Th2 cytokine production were also detected after the first dose of measles vaccination. No study to date has evaluated the pattern of Th17 T cells in response to the measles vaccine. It has been suggested that Th1 cells have a direct role in the clearance of measles vaccine protein antigen, whereas Th2 and Th17 play indirect roles by induction of immune cells recruitment and antibody production. ${ }^{27,28}$ Another study also reported an increase of measles-specific $\mathrm{T}$ cell proliferation in 3-months after the 

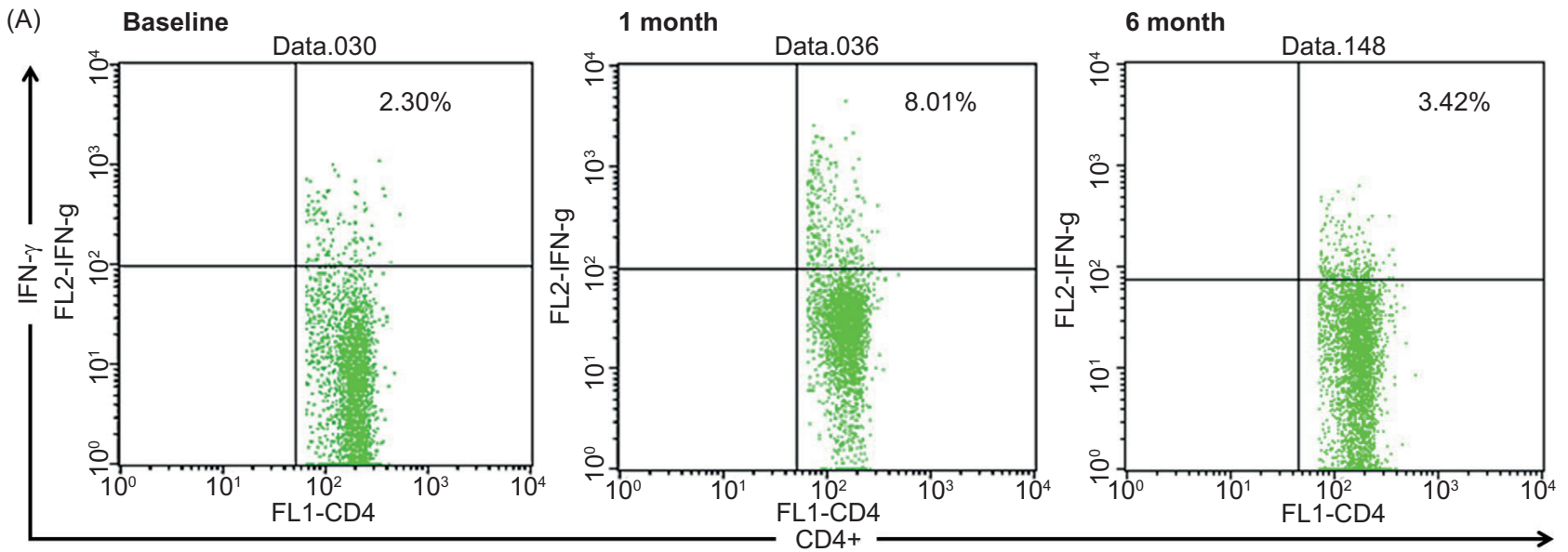

(B)
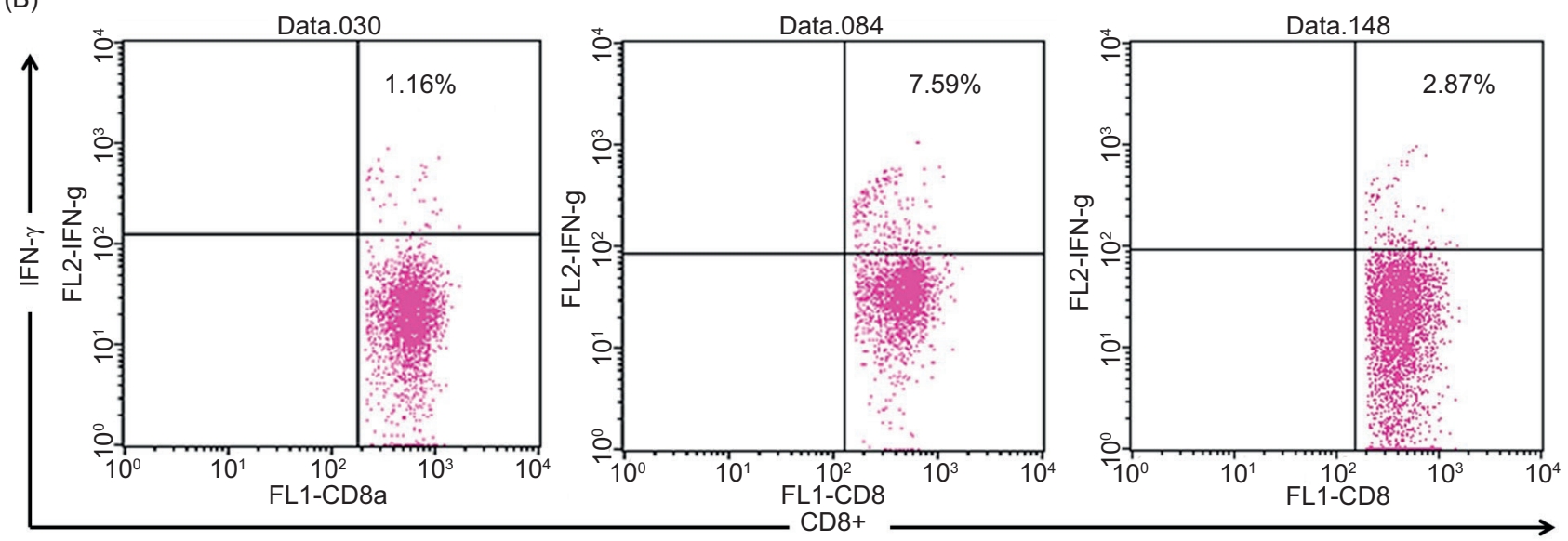

(C)

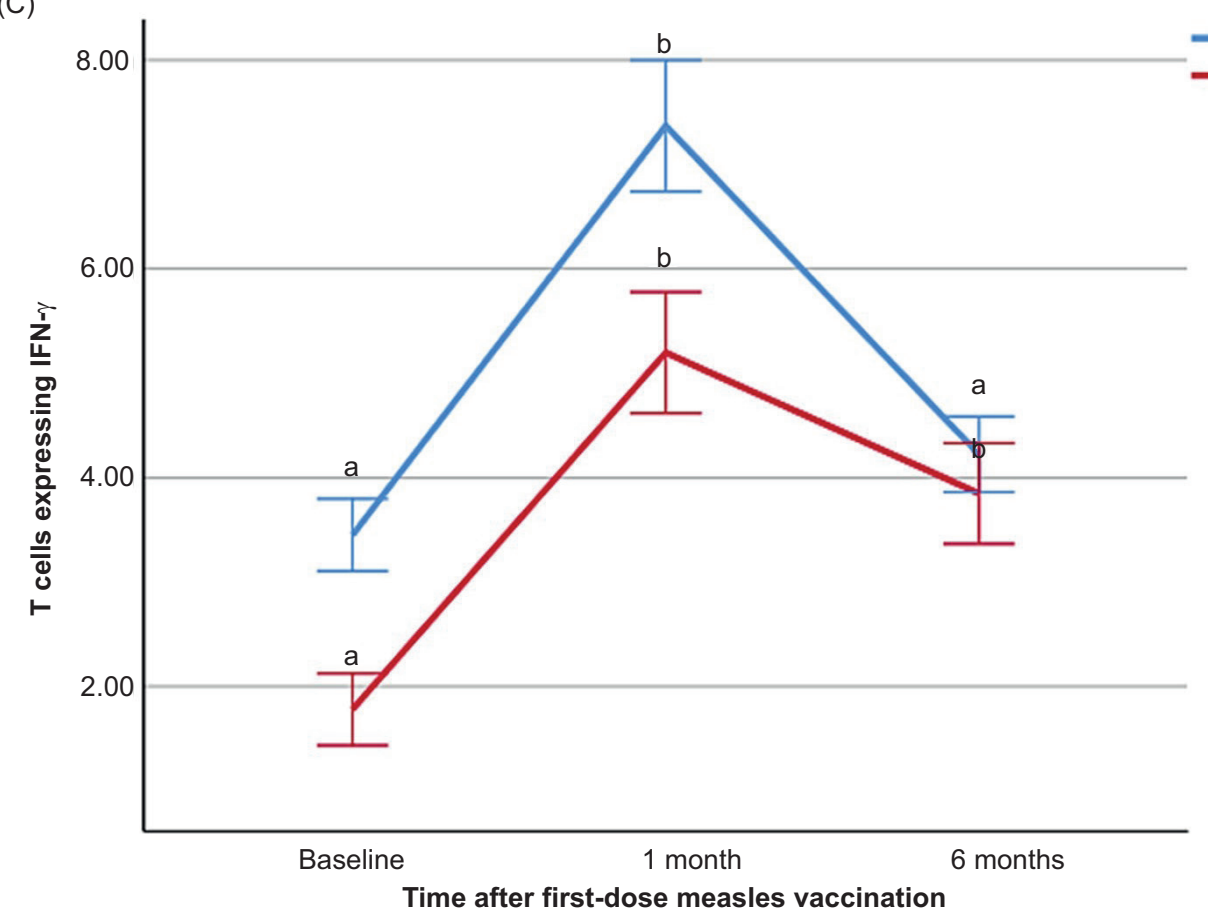

Figure 3 Flow cytometric analysis of T cell producing IFN-g. Gated CD4+ IFN- $\gamma^{+}$cells at baseline, 1- and 6-months after measles EZ vaccination (A). Gated CD8+ IFN- $\gamma^{+}$cells at baseline, 1- and 6-months after measles EZ vaccination (B). Comparison of CD4 ${ }^{+}$and $\mathrm{CD}^{+} \mathrm{T}$ cells expressing IFN- $\gamma$ overtime of evaluation $(\mathrm{C}) .{ }^{*} p<0.05$ was significant statistically (Mann-Whitney test). 

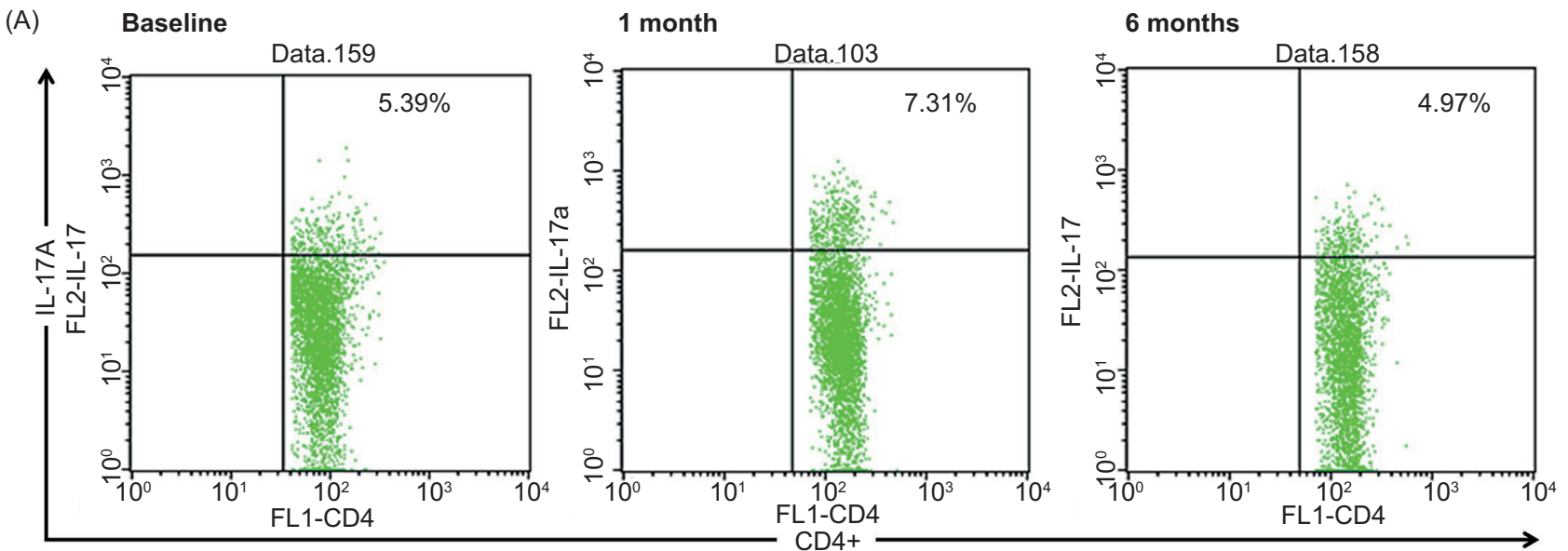

(B)
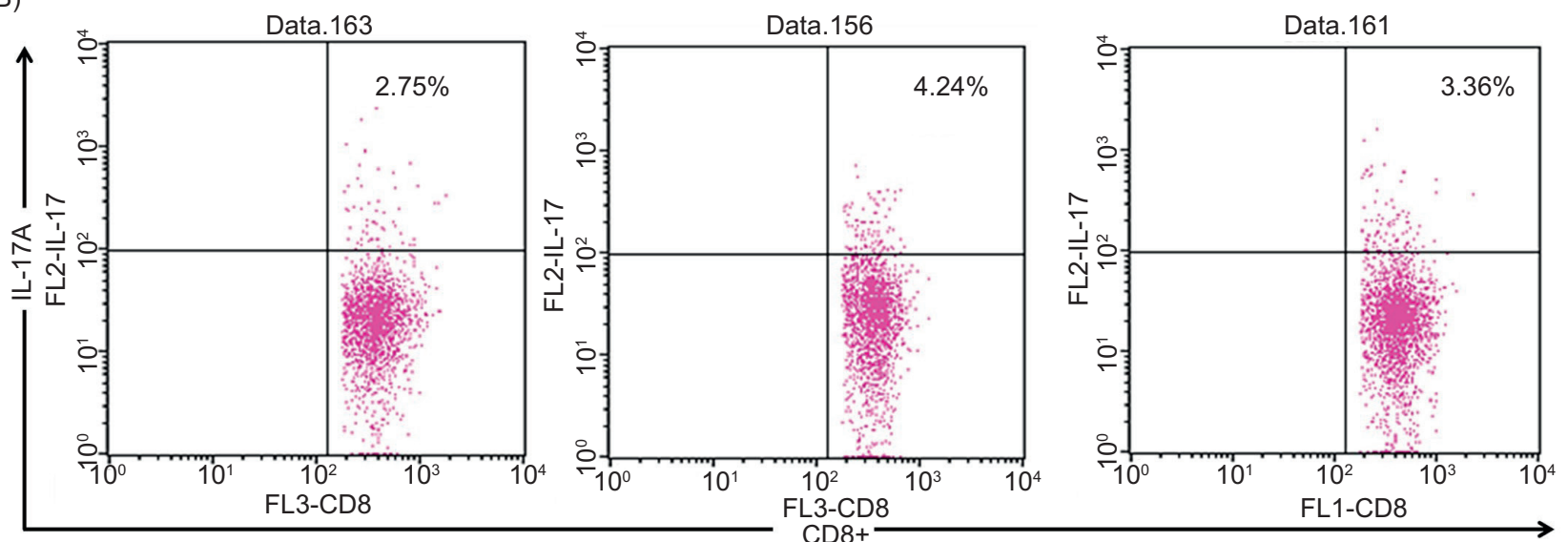

(C)

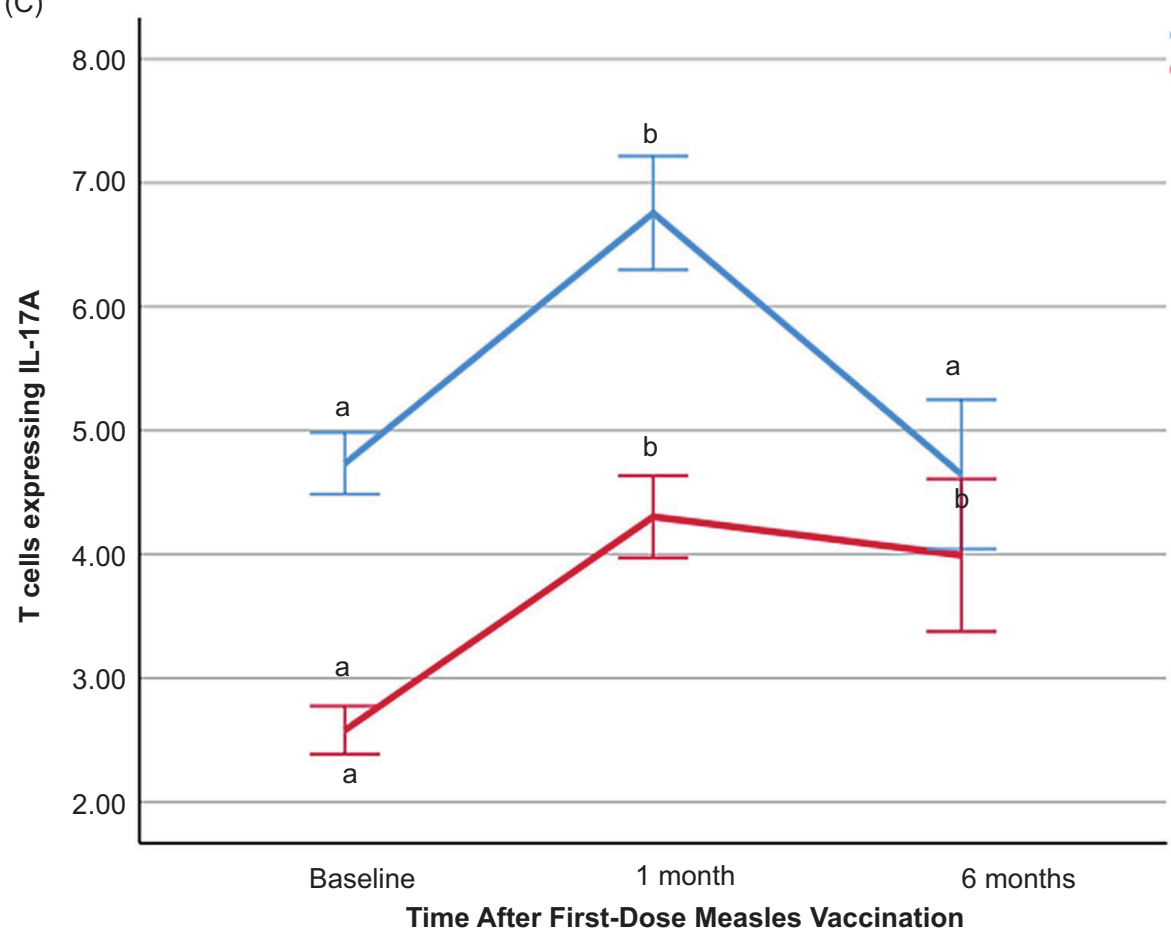

Figure 4 Flow cytometric analysis of T cell producing IL-17A. Gated CD4+ IL-17A+ cells at baseline, 1- and 6-months after measles EZ vaccination (A). Gated CD8+ IL-17A+ cells at baseline, 1- and 6-months after measles EZ vaccination (B). Comparison of CD4+ and CD8 ${ }^{+} T$ cells expressing IL-17A over time of evaluation $(C) .{ }^{*} p<0.05$ was statistically significant (Mann-Whitney test). 
Table 3 Correlation analysis of cellular immune response and measles antibody level.

\begin{tabular}{|c|c|c|}
\hline $\begin{array}{l}\text { Immune response parameters to } \\
\text { measles antibody level }\end{array}$ & $\mathrm{p}$ Value & $r$ \\
\hline $\mathrm{CD} 4^{+}$IFN- $-\gamma^{+}$ & $0.003^{*}$ & 0.320 \\
\hline $\mathrm{CD}^{+} \mathrm{IFN}^{-} \mathrm{\gamma}^{+}$ & $0.004^{*}$ & 0.315 \\
\hline $\mathrm{CD}^{+} \mathrm{IL}^{-17 \mathrm{~A}^{+}}$ & $0.002^{*}$ & 0.331 \\
\hline CD8 ${ }^{+} \mathrm{IL}^{-17 \mathrm{~A}^{+}}$ & $0.000^{*}$ & 0.376 \\
\hline
\end{tabular}

${ }^{*} p<0.05$ was significant statistically (Spearman Correlation test).

$r$ : correlation coefficient.

initial measles vaccine and 6-months after the second-dose measles vaccine in 6- or 9-month-old infants..$^{14}$ In this study, $\mathrm{CD}^{+}$and $\mathrm{CD}^{+} \mathrm{T}$ cells producing IFN-y and IL-17A decrease at 6-months after vaccination. This outcome supports the necessity of the second dose of the measles vaccine to increase cellular immune response. There were limited studies that explained the evolution of $\mathrm{CD}^{+}$or $\mathrm{CD} 8^{+} \mathrm{T}$ cells in the measles vaccine response. Hence this is not fully understood. ${ }^{29}$

Our study demonstrated that the measles vaccine T-cell responses follow a similar pattern with humoral immunity. The number of $\mathrm{CD}^{+}$and $\mathrm{CD}^{+} \mathrm{T}$ cells producing IFN- $\mathrm{\gamma}$ and IL-17A were correlated with measles-specific IgG antibody levels. Another study also indicated high antibody titers and cell-mediated immune responses at 3-4 weeks after measles vaccination. ${ }^{30}$ The study by Laksono et al. ${ }^{11}$ reported no relationship between any specific cytokine level and measles antibody level even though there was an increase of humoral and cellular immune responses after the early-dose measles vaccine.

\section{Strengths and limitations}

This study has several limitations. First, this study was conducted with a short time of evaluation. Long-term evaluation of immune response against measles vaccine can be pivotal in evaluating the measles vaccine immune response for deciding on its booster dose administration. Second, this study was single centered, with limitations such as minimal sample size, which can hinder the outcome interpretation. Lastly, many confounding factors such as nutritional status associated with vaccine immune response were not studied.

Being the first pilot study evaluating specific immune responses to the EZ measles vaccine in Indonesian infants was the strength of this study.

\section{Conclusion}

In conclusion, the first dose of the EZ measles vaccine in 9-months-old infants increased humoral and cellular immune responses at 1-month after vaccination. However, it tended to decrease at 6-months. This pilot study conducted in Indonesia evaluated the specific immune response to measles vaccine. Further multicenter studies with large samples should evaluate this study's outcomes.

\section{References}

1. Poland GA, Jacobson RM. The re-emergence of measles in developed countries: time to develop the next-generation measles vaccines? Vaccine. 2012;30(2):103-4. https://doi. org/10.1016/j.vaccine.2011.11.085

2. Centers for Disease Control and Prevention. Measles (rubeola): history of measles; 2018 [accessed 15 June 2020]. https:// www.cdc.gov/measles/about/history.html

3. Fraser-Bell CJ. Global re-emergence of measles-2019 update. Global Biosecurity. 2019; 1(3):1-10. http://doi.org/10.31646/ gbio. 43

4. World Health Organization, UNICEF. WHO and UNICEF estimates of immunization coverage; 2020 [accessed 01 Aug 2020]. https://www.who.int/immunization/monitoring_surveillance/data/idn.pdf?ua $=1$

5. Ministry of Health of the Republic of Indonesia. Profil kesehatan Indonesia tahun 2017 [Health profile of Indonesia in 2017]. Jakarta: Ministry of Health of the Republic of Indonesia. https://pusdatin.kemkes.go.id/resources/download/pusdatin/profil-kesehatan-indonesia/Profil-Kesehatan-Indonesiatahun-2017.pdf

6. World Health Organization. Measles and rubella surveillance data; 2020 [accessed 20 June 2020]. https://www. who.int/immunization/monitoring_surveillance/burden/vpd/ surveillance_type/active/measles_monthlydata/en/

7. The Straits Times. Indonesia declares end to deadly Papua measles outbreak; 2018 [accessed 15 June 2020]. https:// www.straitstimes.com/asia/se-asia/indonesia-declaresend-to-deadly-papua-measles-outbreak

8. World Health Organization. The immunological basis for immunization series: module 7: measles: update 2020; 2020 [accessed 29 June 2020]. https://apps.who.int/iris/ handle/10665/331533

9. Gans HA, Yasukawa LL, Sung P, Sullivan B, DeHovitz R, Audet S, et al. Measles humoral and cell-mediated immunity in children aged 5-10 years after primary measles immunization administered at 6 or 9 months of age. J Infect Dis. 2013;207:574-82. https://doi.org/10.1093/infdis/jis719

10. Griffin DE. The immune response in measles: virus control, clearance and protective immunity. Viruses. 2016;8:282. https://doi.org/10.3390/v8100282

11. Laksono BM, Grosserichter-Wagener C, de Vries RD, Langeveld SAG, Brem MD, van Dongen JJM, et al. In vitro measles virus infection of human lymphocyte subsets demonstrates high susceptibility and permissiveness of both naive and memory B cells. J Virol. 2018;92:e00131-18. https://doi.org/10.1128/ JVI.00131-18

12. Martins C, Garly ML, Bale C, Rodrigues A, Njie-Jobe J, Benn CS, et al. Measles virus antibody responses in children randomly assigned to receive standard-titer Edmonston-Zagreb measles vaccine at 4.5 and 9 months of age, 9 months of age, or 9 and 18 months of age. J Infect Dis. 2014;210:693-700. https://doi. org/10.1093/infdis/jiu117

13. Kurubi J, Vince J, Ripa P, Tefuarani N, Riddell M, Duke T. Immune response to measles vaccine in 6-month-old infants in Papua New Guinea. Trop Med Int Health. 2009;14:167-73. https://doi.org/10.1111/j.1365-3156.2008.02214.x

14. Gans HA, Ren J, Yasukawa LL, Alderson A, Rinki M, DeHovitz R, et al. Humoral and cell-mediated immune responses to an early 2-dose measles vaccination regimen in the United States. J Infect Dis. 2004;190:83-90. https://doi.org/10.1086/421032 
15. Pan L, Zhang W, Liang Z, Wu X, Zhu X, Li J, et al. Association between polymorphisms of the cytokine and cytokine receptor genes and immune response to hepatitis $B$ vaccination in a Chinese Han population. J Med Virol. 2012;84:26-33. https:// doi.org/10.1002/jmv.22251

16. Njie-Jobe J, Nyamweya $S$, Miles DJC, van der Sande $M$, Zaman S, Touray E, et al. Immunological impact of an additional early measles vaccine in Gambian children: responses to a boost at 3 years. Vaccine. 2012;30:2543-50. https://doi. org/10.1016/j.vaccine.2012.01.083

17. Nelson AN, Putnam N, Hauer D, Baxter VK, Adams RJ, Griffin DE. Evolution of T cell responses during measles virus infection and RNA clearance. Sci Rep. 2017;7:1-10. https://doi. org/10.1038/s41598-017-10965-Z

18. Anichini G, Gandolfo C, Fabrizi S, Miceli GB, Terrosi C, Savellini GG, et al. Seroprevalence to measles virus after vaccination or natural infection in an adult population, in Italy. Vaccines. 2020;8:1-12. https://doi.org/10.3390/vaccines8010066

19. World Health Organization. WHO expert committee on biological standardization, $6^{\text {th }}$ report. Geneva, Switzerland: World Health Organization; 2013. https://www.who.int/biologicals/ expert_committee/TRS_978_61st_report.pdf?ua=1

20. Lochlainn LMN, de Gier B, van der Maas N, van Binnendijk R, Strebel PM, Goodman T, et al. Effect of measles vaccination in infants younger than 9 months on the immune response to subsequent measles vaccine doses: a systematic review and meta-analysis. Lancet Infect Dis. 2019;19:1246-54. https://doi. org/10.1016/S1473-3099(19)30396-2

21. LeBaron CW, Beeler J, Sullivan BJ, Forghani B, Bi D, Beck C, et al. Persistence of measles antibodies after 2 doses of measles vaccine in a postelimination environment. Arch Pediat Adol Med. 2007;161:294-301. https://doi.org/10.1001/ archpedi.161.3.294

22. Hussain H, Akram DS, Chandir S, Khan AJ, Memon A, Halsey NA. Immune response to 1 and 2 dose regimens of measles vaccine in Pakistani children. Hum Vaccines Immunother. 2013;9:2529-

32. https://doi.org/10.4161/hv.25993

23. James SH. Measles, Mumps and rubella viruses. In: Cohen J, Powderly WG, Opal SM, editors. Infectious disease. 4th ed. New York: Elsevier; 2017, p. 1399-1405. https://doi. org/10.1016/B978-0-7020-6285-8.00163-5

24. Fisker $A B$, Nebie $E$, Schoeps A, Martins $C$, Rodrigues A, Zakane $A$, et al. A two-center randomized trial of an additional early dose of measles vaccine: effects on mortality and measles antibody levels. Clin Infect Dis. 2018;66:1573-80. https://doi.org/10.1093/cid/cix1033

25. Carazo S, Billard MN, Boutin A, de Serres G. Effect of age at vaccination on the measles vaccine effectiveness and immunogenicity: systematic review and meta-analysis. BMC Infect Dis. 2020;20:251. https://doi.org/10.1186/s12879-020-4870-x

26. Lin WHW, Pan CH, Adams RJ, Laube BL, Griffin DE. Vaccineinduced measles virus-specific $T$ cells do not prevent infection or disease but facilitate subsequent clearance of viral RNA. mBio. 2014;5:e01047-14. https://doi.org/10.1128/ mBio.01047-14

27. Nakayamada S, Takahashi H, Kanno Y, O’Shea JJ. Helper T cell diversity and plasticity. Curr Opin Immunol. 2012;24:297-302. https://doi.org/10.1016/j.coi.2012.01.014

28. Lin Y, Slight SR, Khader SA. Th17 cytokines and vaccine-induced immunity. Semin Immunopathol. 2010;32:79-90. https://doi.org/10.1007/s00281-009-0191-2

29. Busch E, Kubon KD, Mayer JKM, Pidelaserra-Martí G, Albert J, Hoyler B, et al. Measles vaccines designed for enhanced CD8 $^{+}$T cell activation. Viruses. 2020;12:242-9. https://doi. org/10.3390/v12020242

30. Bautista-López NL, Vaisberg A, Kanashiro R, Hernández $H$, Ward BJ. Immune response to measles vaccine in Peruvian children. Bull World Health Organ. 2001;79:1038-46. 